San Antonio Review • WordPress Imports (Pending Organization) - Ian: You can use this.

\title{
Getting it Down
}

Published on: Oct 06, 2019

License:Creative Commons Attribution 4.0 International License (CC-BY 4.0). 
By Anna Schott

An essay in two parts: the first, written by my friend Ken, is about me. The second, written by me after he died, is about him.

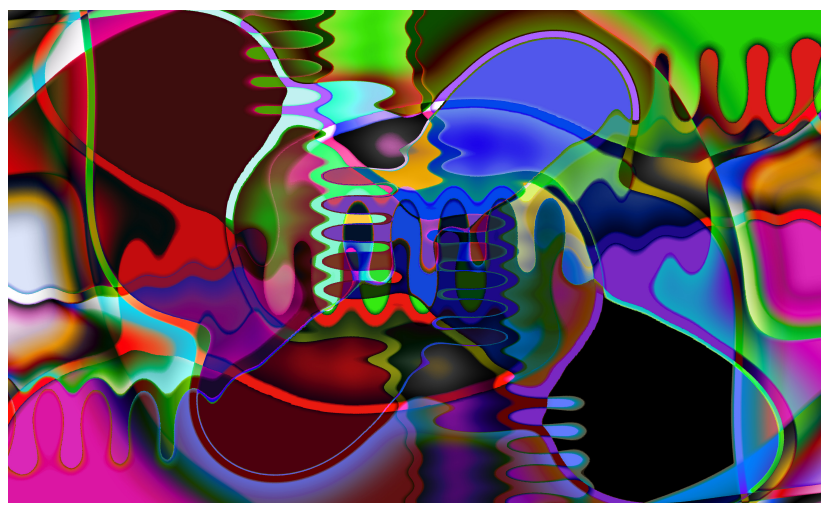

Anna at Four Years of Age

by Ken Ellyson

Spectrum, 1978

"She was a little bright wave of willfulness, so abandoned to her impulses, so white and smooth as she lay at rest, so startling as she flashed her naked limbs about. But she was growing too old for a young man to undress._"-

-D. H. Lawrence "The Old Adam"

1.

Anna stood at the window, resting her head at the sill. I came and kneeled beside her. "What are you doing?" I asked. "Calling Mischa," she said-then called "Mischa, Mischa," in a tiny voice.

"He can't hear you unless you call louder," I said; I yelled "Mischa" as loud as I could, then we listened, but no one answered. 
Anna gazed out the window with an abstract look in her eye, and said dreamily, "Maybe he's dead."

"Maybe," I said, "but I doubt it."

She held that dreamy look for a moment, then grinned slyly and looked at me from the corner of her eye.

"He's not dead, Ken," she said, and hit me on the shoulder and ran.

2.

For a long time her favorite trick was to pull her pants down and waggle her butt in my face- nothing delighted her so much as a little slap on the butt, or an ogre-ish spanking from me with lots of noise and yelling. But one day, in an excess of excitement, while I was sitting in the front yard of her house, she ran out and pulled her pants down. I ignored her, and she said "Watch, Ken, I'm going to pee on the sidewalk." I said "So what?" and looked away. She said "Did you pee on the sidewalk when you were little?"

I said "No."

"Would your mommy get mad at you?"

"If I had done it she would have been mad."

"Look," she said, "I'm peeing on the sidewalk," and I looked and she was. She wasn't looking at me, she was watching the pee run down the walk. 
I allowed myself to look away, embarrassed.

She stood up and pulled up her pants and then we went into the house.

3.

Once when Anna's grandmother was over, there was an argument about grandmothers. Her grandmother had had strokes and was in a wheelchair; her memory was very faulty. While Anna's father was talking to her grandmother, Anna came in. She listened for a bit, then in a pause she asked her father "Do you have a grandma?" He said "I had a grandma but now she's dead." Anna began to ask "how did she die?" but her grandmother cut her off, saying irritably "she's not dead, she's not dead." Anna looked at her, then back to her father, who said "She is dead, Mother; remember? She died 15 years ago."

"She's not dead."

"Yes, she is dead."

"She is not dead."

Anna turned her head from one to the other, looking frightened. Her father said to her in a quieter voice: "My grandmother is dead, Anna," and though Anna looked at her grandmother, there was no more argument. Anna left the room looking worried, and there was no more heard on the subject that day. But late at night she came crying into her parents' bedroom, and would only be comforted by her mother, and 
said she had had a dream about her grandma being dead- "A big dog took her away," she said.

Getting it Down

Ken moved into my parents' house in 1977, when I was four years old. He must have been about eighteen. His own parents, back in Georgia, had kicked him out after he told them he was gay. He moved to California and enrolled as a writing student at the small college where my father was a teacher. He was one of the brightest students at the college and a brilliant writer. It was an unusual school in some ways, where students and teachers often became friends. My father brought Ken home one day to meet the family, and not long afterward he moved in. He lived with us, in the spare room downstairs, until he graduated.

I remember him at first as being full of fun-almost too wild, unlike other adults, and more like me. I remember how I would prance naked in front of him, begging him to chase me, which he did--tackling and tickling me until I wept with exhaustion. It occurs to me now that some might think he was a bit inappropriate in his physical dealings with a 4year-old girl.

We were too alike. In our wildness, we indulged every impulse. It was exhilarating, but as a little kid I couldn't self-regulate, and Ken didn't regulate me at all. Finally, to my disappointment (and secret relief) my mother told him that he shouldn't be so rough with me, that though I 
screamed in delight I was also afraid ... and there was an end to our fun.

Ken moved to San Francisco after college. This was in the early '80s, during the beginning of the Aids epidemic in the Castro. After a few years in San Francisco, when I was about eleven, he moved back to our town.

He came over to the house one afternoon. I was shy to greet him at first, but his loud laugh and affectionate behavior soon put me at ease.

Besides, he was someone I had lived with, and loved, growing up.

My mother served some food. We stood around on the patio and ate. We joked around for a while. Ken told wild stories about all the boyfriends he'd had in the city, then became quiet.

"Pleasure has its price though right?" he said. Then: "I got the virus."

My parents looked grim. I didn't understand.

"A disease for faggots" he explained. "Punishment for giving good blow jobs. I'll die of it, someday, but not for a long time."

I looked at him. He was smiling.

"A long time," he said again, "and definitely not until after you're all grown up, which is like, forever, right?"

I smiled back. 
We spent a lot of time together after that. I was glad to have a grown-up friend who took me seriously, although he would often tease me, in a softly mocking tone, with his barely discernible Georgia accent. But he was big-hearted. Physically he was slight and wiry, but everything else about him was big. The way he'd throw his head back and laugh, a huge, loud laugh. He was quick and bright and loved to talk. And when I talked he'd lean in and listen, giving me his full attention. He was affectionate and persuasive and flirted with everyone. Sometimes, as a kind of game, he'd try to convince his straight male friends to fool around with him. Sometimes he'd succeed, too.

My parents would give dinner parties for the teachers and students at the college, where Ken's genius-not as a seducer-but as thinker and writer, was widely acknowledged. Everyone would come over. My mother would cook. There would be wine. The adults ate and drank and talked about music and movies and books and art while I sat and listened. Mostly everyone was staid and well behaved, but then there was Ken. He was never drunk but was invariably loud, almost wild. He laughed and made everyone else laugh. One night he came over for dinner with some other students-a couple. They had given him a ride in their truck. "I got to sit in the middle," said Ken, as they came into the house. "I gave them both handjobs on the drive here." He threw back his head and laughed. The couple looked startled, a little embarrassed. I stared, embarrassed myself. I wasn't sure if he was joking, but I hoped not. 
I guess Ken was something like a big brother, one who doted on me. When I went away to violin camp in the summers he would send me cards-one card a week for the eight weeks that I was gone. Inside the cards, he would write about what he'd been doing that week, often with little cartoon-like drawings to illustrate. His words (and drawings) were silly and sometimes obscene, but his tone was always lively and affectionate. I was touched by these efforts to amuse me; I felt the luck of it.

And he was generous. Later, when I'd gone off to college, he insisted on sending me fifty dollars a month of "free" money. "It's for you to do whatever you want with," he said. "Throw it away, burn it, I don't care. I'm just sorry I can't send more."

As I grew older our relationship changed a little-I thought he was cute and he knew it. He started holding my hand when we walked or putting his arm around me. "Can I be your boyfriend?" he'd say, mercilessly, as I blushed to my ears and stared at the ground. I hated him then, because I knew, as a girl, how safe I was. For a few years, I wanted nothing more than to be a boy, a cute one, who Ken would actually be interested in.

In junior high, I was learning that to be anything other than homophobic was unacceptable. I found that I couldn't relate to the other kids. I started cutting classes. Some stoners had shown me where there was a hole in the fence behind the track field. At lunchtime, I'd make sure that no one was watching, then squeeze through the hole 
and walk downtown to the library where Ken had a part-time job doing something that didn't seem to require much attention. I'd hang out in his cubicle, talk to him about boys, or read if he had work to do. On weekends we'd go hiking. Later, in high school, I had boyfriends. I'd bring them over to Ken's apartment. I wanted to show him off. And it was a test: “This is my cool, cute, brilliant-gay friend. If he doesn't love you then I certainly can't." I was proud and defensive of him when it seemed like everyone in the world was a bigot. Alone with Ken, I'd ask: "Well? Isn't he cute? Will he do?"

Ken despised officiousness and taught me to laugh at prudery. We would act deliberately obscene if we sensed a prude or phony in our midst. He might say something like: "So I was making out with my boyfriend last night..." and then wink at me. In the mid-eighties, this was provocative enough to get him beaten up.

"Did you blow him?" I'd ask, thrilled at my own audacity. We'd stop talking and watch for a reaction. And sure enough, expressions would harden-eyes would narrow, lips purse in disapproval. It was confirmation that they deserved it. It was fun and kind of pathetic all at once for us to do this but most importantly it was defiant. An attempt to "own it", when owning it meant being attacked, ostracized, despised.

That kind of goofing around was in more or less innocent fun, but as Ken got sicker he started to become unpleasant. His personality, or the part of his personality that might depend on being in good health, and 
not being in pain, had changed. He grew thinner, more and more irritable.

But his laugh was still loud. And he still showed me flashes of his old affection.

He was very thoughtful and deliberate about dying, or the process, which took several years, of coming to die. And he was thoughtful and deliberate in the ways that he tried to prepare me.

I remember one time when we were hiking up in the mountains a couple of years before he died. We were halfway up a switchback on Rattlesnake trail and had stopped to catch our breath. We sat down on a large rock that looked out over the canyon. We sat close together. I leaned my head on his shoulder. He was quiet for a moment, then pulled out his wallet and started looking through it. "Look, I'm a member," he said and handed me what looked like a business card. I looked. The card had a drawing of a tree on it, and said "Hemlock Society".

"I don't understand" I said.

"It's a pill to help me die" he said.

"Oh."

"It's the only club that would have me" he added, and laughed. 
Eventually, he began to get really sick. The disease was attacking his nervous system. But he continued to work at the library, while living, very thriftily, in a room that he rented from a friend. He had plenty of friends who would have helped him, but he was adamant about being self-sufficient. He was saving up to buy a motorcycle. Something he had always wanted. He brought it over one day and gave me a ride around the block. It was a big, red, ugly thing. Expensive. He looked like hell, sitting on it, weak and emaciated. I was afraid we'd fall off. After a couple of months, he became too sick to ride. He still worked at the library though. He wanted to keep working as long as he could, he said, so that he could "pay off the bike in time."

Ken went downhill fast after he paid off the bike. He was dizzy, in pain, could barely stand. He was thirty-six. I was nineteen, and had just gone back to Ohio for my second year of music school. I had been unsure about leaving. "No" he had said. "You go. Maybe I'll come visit. We can molest all of the cute boys."

Back at home, my mother had started to make the rounds of her doctor friends, one of whom agreed to give her some morphine, which she delivered regularly to Ken-sometimes along with soup. It wasn't long before he was beyond the soup. Finally he called me at school to say goodbye-although he didn't say it-not in so many words. I pretended not to know why he was calling. I asked if I could come home and see him. 
"I'm too sick" he said. "I don't want you to see me like this. And I don't want to see anybody anyway."

"Well, I'll be home for spring break" I said, "maybe you'll be feeling better by then."

He said something, jokingly-that stranger things had happened, maybe-and we hung up.

The next day he wrote a-very affectionate-note to my dad, who he had made executor of his will, asking him to call the funeral home, where he'd already arranged things. He waited for his friend to go out. Then he lay down on his bed, with the note in his hand, and took the pill.

I tried then and still do try although without much success to imagine what that must have been like-how he could have had the wherewithal: to put things in order, to pay off the bike, to obtain and set aside the pill, to arrange with the funeral home, to write the note to my dad, to wait until his friend went out, to think of everything... but most of all, and what troubles me the most, although I admire it too, is how he did it-how he died, entirely alone.

My dad told me recently how a couple of guys from the funeral home had come in a big car to take Ken away. They put on their gloves before touching him, but even then they were uncomfortable, because they knew he'd had AIDS. "It was very awkward" said my dad. "I can still remember the look on the younger guy's face." 
When Ken died I sort of dissolved. I dropped out of school and went home. Some days were harder than others. At night I would write. I wrote down every conversation with Ken that I could remember. To my surprise and relief, I could still hear him speak, his voice, as I wrote.

I wrote about him for a few months and then stopped. There was a lot to think about and write and remember. It hurt when I realized that I couldn't remember anything more. The memory is finite, I guess, in the way that a person can live on in your mind, but only up until a certain point. I had a good fifty pages though, now lost, of him-everything I could remember.

I'd gotten it, too. I'd gotten him down.

Anna Schott is a violinist and writer. She lives in Brooklyn with her family.

Image: “Lost Dreams 2," digital painting, 2019, Edward Supranowicz

Edward Michael Supranowicz has had artwork and poems published in the U.S. and other countries. Both sides of his family worked in the steel mills and coalmines of Appalachia. 